\title{
Glycolytic activity in human synovial lining cells in rheumatoid arthritis
}

\author{
B. HENDERSON, LUCILLE BITENSKY, AND J. CHAYEN \\ From the Division of Cellular Biology, Kennedy Institute of Rheumatology, Bute Gardens, London
}

SUMMARY It was conceivable that the previously reported elevated pentose-shunt activity in human rheumatoid synoviocytes could be at the expense of glycolytic activity. To test this possibility the activities of glyceraldehyde 3-phosphate and lactate dehydrogenase, the two dehydrogenase enzymes of the latter pathway, have been investigated in the synovial lining cells in fresh sections of nonrheumatoid and rheumatoid synovial tissue. To measure the activity solely in the lining cells, apart from that in underlying infiltrating cells, quantitative cytochemical reactions have been used; the activities were measured by microdensitometry. The results showed highly and significantly increased activity of both enzymes in the rheumatoid cells. Increased activity was also found in synoviocytes in nonrheumatoid synovial tissue after trauma, so that the increased activity of these enzymes is not characteristic of the rheumatoid condition. However, the results indicate that the increased pentose shunt activity in rheumatoid synovial lining cells is not at the expense of glycolytic activity but may be part of an enhanced potential for utilising glucose 6-phosphate in these cells.

Both Dingle and Page-Thomas (1956) and Roberts et al. (1967) showed that the activity of the glycolytic (Embden-Meyerhof) pathway was increased in human rheumatoid synovial tissue. However, this result could be due to the infiltrating cells present in rheumatoid tissue in contrast to the relative lack of such cells in nonrheumatoid synovial tissue; it did not show conclusively that the oxidative metabolism of the synoviocytes was altered with regard to this pathway.

This question could be resolved only by quantitative cytochemistry, in which the activity of each cell type, defined histologically, can be measured separately from the surrounding cells. Such cytochemical investigations had shown that the activity of glucose 6-phosphate dehydrogenase, the first and rate-limiting step (Eggleston and Krebs, 1974) of the hexose monophosphate pathway (or pentose-shunt), is about 4 times that found in nonrheumatoid synovial lining cells (Butcher et al., 1973), confirmed by Henderson (1977). Since both the glycolytic and the hexose monophosphate pathways compete for glucose 6-phosphate it was of interest to determine whether or not the increased pentose shunt activity

Accepted for publication 17 April 1978

Correspondence to $\mathrm{Dr} \mathrm{J}$. Chayen, Kennedy Institute of Rheumatology, Bute Gardens, London W6 7DW. in the synovial lining cells was at the expense of the glycolytic activity.

The major function of the glycolytic pathway is to provide the substrate for mitochondrial oxidation and thus for the synthesis of adenosine triphosphate (ATP), which is regarded as the normal 'energy currency' of the cell. Wilkinson and Robinson (1974) showed that the release of enzymes from certain cells may be a consequence of diminished intracellular concentrations of ATP.

\section{Materials and methods}

Specimens of human nonrheumatoid synovial tissue were obtained from the knee joint during routine arthrotomy. The rheumatoid synovial tissue was taken at synovectomy from patients with 'definite' or 'classical' disease (Ropes et al., 1959). All specimens were taken in a bloodless field but within $10 \mathrm{~min}$ of the application of the tourniquet. Table 1 gives the details of the patients. Pieces of tissue approximately $4 \times 4 \times 4 \mathrm{~mm}$, were chilled by precipitate immersion in $n$-hexane (BDH 'free from aromatic hydrocarbons' grade; boiling range $67-70^{\circ} \mathrm{C}$ ). After not longer than $1 \mathrm{~min}$ the specimen was removed from the hexane and stored at $-70^{\circ} \mathrm{C}$ in a corked dry glass tube. Specimens were sectioned at $10 \mu \mathrm{m}$ in a Bright's cryostat maintained at a 
Table 1 Specimens and patients studied

\begin{tabular}{|c|c|c|c|c|c|}
\hline \multicolumn{3}{|c|}{ (a) Non rheumatoid } & \multicolumn{3}{|c|}{ (b) Rheumatoid } \\
\hline Specimen no. & Sex & $\begin{array}{c}\text { Age } \\
(y r)\end{array}$ & Specimen no. & Sex & $\begin{array}{l}\text { Age } \\
\text { (yr) }\end{array}$ \\
\hline $\begin{array}{l}1604 \\
1632 \\
1652 \\
1655 \\
1656 \\
1712 \\
1717 \\
1824 \\
1877 \\
1883 \\
1916 \\
1935 \\
1982 \\
1989\end{array}$ & $\begin{array}{l}\mathbf{F} \\
\mathbf{F} \\
\mathbf{M} \\
\mathbf{F} \\
\mathbf{M} \\
\mathbf{M} \\
\mathbf{M} \\
\mathbf{M} \\
\mathbf{M} \\
\mathbf{F} \\
\mathbf{M} \\
\mathbf{M} \\
\mathbf{M} \\
\mathbf{M}\end{array}$ & $\begin{array}{l}54 \\
14 \\
21 \\
14 \\
20 \\
31 \\
20 \\
19 \\
23 \\
19 \\
12 \\
23 \\
21 \\
44\end{array}$ & $\begin{array}{l}1599 \\
1611 \\
1612 \\
1626 \\
1692 \\
1709 \\
1711 \\
1722 \\
1815 \\
1819 \\
1854 \\
1912 \\
1928 \\
1965 \\
1970\end{array}$ & $\begin{array}{l}\mathbf{F} \\
\mathbf{F} \\
\mathbf{F} \\
\mathbf{F} \\
\mathbf{F} \\
\mathbf{F} \\
\mathbf{M} \\
\mathbf{F} \\
\mathbf{F} \\
\mathbf{F} \\
\mathbf{F} \\
\mathbf{F} \\
\mathbf{F} \\
\mathbf{F} \\
\mathbf{F}\end{array}$ & $\begin{array}{l}- \\
- \\
44 \\
43 \\
64 \\
47 \\
68 \\
63 \\
70 \\
48 \\
50 \\
52 \\
68 \\
53 \\
47\end{array}$ \\
\hline
\end{tabular}

cabinet temperature of -25 to $-30^{\circ} \mathrm{C}$ with the knife cooled to $-70^{\circ} \mathrm{C}$ by having solid carbon dioxide packed around its haft. The sections were transferred from the knife to slides from the ambient temperature of the laboratory; this ensured that the sections become flash-dried (Chayen et al., 1973). For each specimen the precise histology was established by staining sections with toluidine blue.

\section{ASSAY OF ENZYMES}

Glyceraldehyde 3-phosphate dehydrogenase (EC 1.1.1.12) catalyses the conversion of glyceraldehyde 3-phosphate to 1, 3-diphosphoglycerate. It is the only oxidative step in the glycolytic pathway to pyruvate, and is the source of reduced nicotinamide adenine diphosphate (NAD). It was assayed by the method of Henderson (1976) in which the substrate is fructose diphosphate. The optimal $\mathrm{pH}$ was $8 \cdot 5$. The procedure therefore tests the efficiency of aldolase activity in converting this substrate to that required by the dehydrogenase; this step can be circumvented by including aldolase in the reaction medium. However, in the absence of exogenous aldolase, this 2-step reaction tests the activity of all this part of the glycolytic pathway. Reducing equivalents produced by the action of the dehydrogenase are transferred quantitatively to neotetrazolium chloride by the intermediate hydrogen acceptor phenazine methosulphate (PMS), which is included in the reaction medium.

Lactate dehydrogenase (EC 1.1.1.27) catalyses the reversible reduction of pyruvate to lactate. In the cytochemical procedure the concentration of lactate and the presence of PMS drive the reaction in the reverse direction, namely, to demonstrate the oxidation of lactate with the concomitant generation of NADH, which reduces neotetrazolium chloride in the presence of PMS to a coloured insoluble formazan which is suitable for microdensitometric measurement (Chayen et al., 1973). The reaction medium was a $22 \%(\mathrm{w} / \mathrm{v})$ solution of polyvinyl alcohol (BO5/140), to stabilise the sections, in 0.05 $\mathrm{mol} / \mathrm{l}$ glycyl glycine buffer, pH $8 \cdot 0$, with $0.3 \%$ neotetrazolium chloride(Merck). To each millilitre of reaction medium were added $5.6 \mathrm{mg}$ sodium lactate (BDH), $2.5 \mathrm{mg} \mathrm{NAD}{ }^{+}$(Boehringer), and $0.2 \mathrm{mg}$ PMS (Sigma). The final $\mathrm{pH}$ of the reaction medium was adjusted as necessary just before adding the medium to the sections.

Henderson (1977) had shown that under these conditions and at $37^{\circ} \mathrm{C}$ the activity of both enzymes in human synoviocytes was linear over the range of up to twice the reaction times used in this study. Optimal times of reaction were $4 \mathrm{~min}$ for glyceraldehyde 3-phosphate dehydrogenase and $10 \mathrm{~min}$ for lactate dehydrogenase activity. The recorded activities were then standardised by relating activity to unit period of time. Consequently unfixed sections were incubated in the appropriate medium for these times at $37^{\circ} \mathrm{C}$ in an atmosphere of moist nitrogen (Chayen et al., 1973). For each estimation, the amount of formazan in each of 20 fields of synovial lining cells (each field being $45 \mu \mathrm{m}$ in diameter) was measured in duplicate or triplicate sections by means of a Vickers M85 scanning and integrating microdensitometer. The wavelength used was $585 \mathrm{~nm}$; the diameter of the scanning spot was $0.5 \mu \mathrm{m}$ with a $\times 40$ objective. The results (relative absorption) were converted to absolute units of extinction (integrated extinction $\times 10^{3}$ ) by suitable calibration.

The significance of the results was tested by Student's $t$ test.

\section{Results}

\section{GLYCERALDEHYDE 3-PHOSPHATE}

DEHYDROGENASE

The activity of this enzyme was measured in synovial lining cells of synovial tissue taken from 5 quiescent nonrheumatoid joints subjected to routine arthrotomy for internal derangements. This activity was low relative to that found in the rheumatoid synovial lining cells (Table 2 ), the difference in activity being highly significant $(0.005>P>0.001)$. These results confirm the earlier study of Henderson (1977). It is noteworthy, however, that the activity in the synovial lining cells in the synovium taken from a recently traumatised knee was as great as the lower activities found in the rheumatoid cells.

\section{LACTATE DEHYDROGENASE}

The activity of lactate dehydrogenase was assayed in 10 specimens of nonrheumatoid and 14 specimens of rheumatoid synovium (Table 3). There was a 
Table 2 Glyceraldehyde 3-phosphate dehydrogenase activity in synovial lining cells

\begin{tabular}{|c|c|c|}
\hline Tissue & $\begin{array}{l}\text { Case } \\
\text { no. }\end{array}$ & $\begin{array}{l}\text { Enzyme activity } \\
\text { (integrated extinction } \\
\times 10^{3} / 10 \text { min) }\end{array}$ \\
\hline $\begin{array}{l}\text { Nonrheumatoid } \\
\text { (a) Quiescent } \\
\text { Mean (and SEM) } \\
\text { (b) Recent Trauma } \\
\text { Rheumatoid }\end{array}$ & $\begin{array}{l}1824 \\
1877 \\
1916 \\
1982 \\
1989 \\
1935 \\
\\
1815 \\
1819 \\
1854 \\
1911 \\
1928 \\
1965 \\
1970\end{array}$ & $\begin{array}{c}4 \\
7 \\
2 \\
22 \cdot 5 \\
9 \cdot 5 \\
9(4) \\
40 \\
\\
49 \\
158 \\
30 \\
54 \\
76 \\
268 \\
134 \\
110(34)\end{array}$ \\
\hline
\end{tabular}

Table 3 Lactate dehydrogenase activity in synovial lining cells

\begin{tabular}{|c|c|c|c|}
\hline \multicolumn{2}{|c|}{ Nonrheumatoid tissue } & \multicolumn{2}{|l|}{ Rheumatoid tissue } \\
\hline Case no. & $\begin{array}{l}\text { Enzyme } \\
\text { activity } \\
\text { (integrated } \\
\text { extinction } \\
\times 10^{3} / \\
10 \mathrm{~min} \text { ) }\end{array}$ & Case no. & $\begin{array}{l}\text { Enzyme } \\
\text { activity } \\
\text { (integrated } \\
\text { extinction } \\
\times 10^{3} / \\
10 \text { min) }\end{array}$ \\
\hline $\begin{array}{l}1604 \\
1632 \\
1652 \\
1655 \\
1656 \\
1712 \\
1717 \\
1877 \\
1883 \\
1935\end{array}$ & $\begin{array}{l}702^{*} \\
491+ \\
442 \dagger \\
274 \\
228 \\
121 \\
77 \\
112 \\
121 \\
416 \ddagger\end{array}$ & $\begin{array}{l}1599 \\
1611 \\
1612 \\
1626 \\
1692 \\
1709 \\
1711 \\
1722 \\
1815 \\
1819 \\
1912 \\
1928 \\
1965\end{array}$ & $\begin{array}{r}790 \\
899 \\
777 \\
1268 \\
600 \\
286 \\
456 \\
248 \\
404 \\
495 \\
352 \\
432 \\
1132\end{array}$ \\
\hline $\begin{array}{l}\text { Mean (and SEM) } \\
\text { Mean for } 6 \\
\text { unmarked } \\
\text { samples }\end{array}$ & $156(26)$ & Mean (and SEM) & $652(88)$ \\
\hline
\end{tabular}

* 4-year history of joint pain.

+ recent trauma; histology suggestive of villonodular synovitis.

$\dagger$ osteochondritis.

$\ddagger$ very recent trauma.

significant difference $(0.01>P>0.005)$ in activity between the 2 populations. Of the 10 nonrheumatoid specimens assayed 6 samples came from quiescent joints with no clinical symptoms other than those of the internal derangement for which the routine arthrotomy was performed. When the lactate dehydrogenase activities in the synoviocytes from these joints were compared with those in the rheumatoid lining cells, the significance of the difference was increased $(P=0 \cdot 001)$.

\section{LACTATE DEHYDROGENASE ACTIVITIES}

IN SYNOVIAL MEMBRANE AND VILLI

By conventional biochemical procedures PageThomas and Dingle (1955) and Roberts et al. (1967) found that villiform rheumatoid synovium produced considerably more lactate than did smooth rheumatoid synovium. These findings might imply that the synoviocytes in the villi have greater glycolytic activity. However, marked differences between these populations of cells were not seen in the course of the present study (Fig. 1), where it was possible to measure the activity of each type separately even in the same preparation.

\section{Discussion}

The impetus for this study was the finding that glucose 6-phosphate dehydrogenase activity was significantly raised in rheumatoid synoviocytes. This enzyme catalyses the oxidation of glucose 6phosphate, which is the initial substrate for the glycolytic pathway. It was therefore possible that, in in the rheumatoid synoviocytes, the increased glucose 6-phosphate dehydrogenase activity would decrease the rate of glycolysis by diminishing the intracellular concentration of glucose 6-phosphate.

A measure of the glycolytic activity of human synoviocytes has been made by assaying the two dehydrogenase enzymes of the glycolytic pathway, namely, glyceraldehyde 3-phosphate dehydrogenase (GAPD) and lactate dehydrogenase (LDH). GAPD is a central enzyme of glycolysis and is one of the molecules which belong to the 'constant proportion' group of enzymes of this pathway. The activities of any one of this 'constant proportion' group of enzymes, if measured under optimal conditions, as used in this study, give a measure of the capacity of the whole pathway (Höhmann and Zwiebel, 1971). Lactate dehydrogenase is the terminal enzyme of glycolysis and catalyses the reoxidation of NADH, produced by the action of GAPD. In cells with low mitochondrial activity, such as human synovial lining cells (Henderson et al., 1978), the rate of glycolysis is dependent on the supply of oxidised NAD (Newsholme and Start, 1973). Consequently the activity of LDH will have a bearing on the rate of glycolysis in such cells.

Thus the finding of a marked and significant increase in both GAPD and LDH activities in rheumatoid synoviocytes strongly suggests that the activity of the glycolytic pathway is increased in these cells. Therefore the increased glucose 6-phosphate dehydrogenase activity is not at the expense of glycolysis.

In contrast to the findings of both Page-Thomas and Dingle (1955) and Roberts et al. (1967), who 

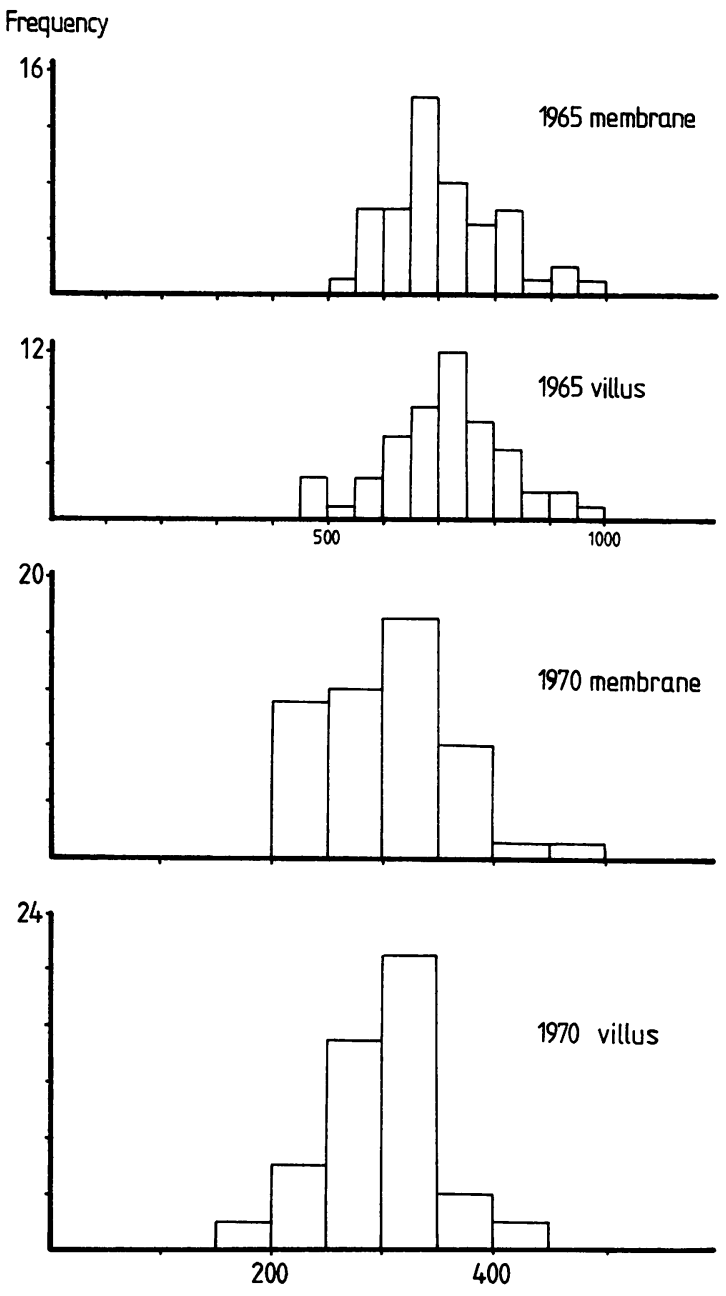

RELATIVE ABSORPTION

Fig. 1 Population histograms showing the lactate dehydrogenase activity in rheumatoid synoviocytes from the flat regions of the synovial membrane (1965 membrane and 1970 membrane) and from the villous processes of these membranes (1965 villus and 1970 villus) in 2 different specimens. These histograms record the frequency with which particular levels of activity (REL. ABS.) are found in these specimens. Although there is some variation in the different populations, the mean activities are practically identical.

reported increased lactate production by rheumatoid synovial villi, as compared with the smoother regions of the membrane, no such differences were found in the course of this investigation (Fig. 1). The activity of lactate dehydrogenase was similar in membrane or villous synoviocytes. Similar results have been found with two other glycolytic enzymes, namely, glyceraldehyde 3-phosphate dehydrogenase and phosphoglucoisomerase (Henderson, 1977). The probable explanation for this discrepancy between the biochemical and cytochemical findings lies in the difference in cellularity between the membranes and villi. Synovial villi are normally composed of a thin rim of lining cells surrounding a core of densely packed infiltrating cells which themselves had glycolytic activity. Thus the amount of noncellular connective tissue in the villi is small. In contrast, the membrane may have a thicker layer of lining cells, but the underlying stroma, though containing some infiltrating cells, is less cellular than in the villi. As metabolic activity in the biochemical assays has been measured in terms of wet weight or tissue nitrogen, this will vary with the amount of proteinaceous noncellular material. The villi, having less noncellular material, will obviously show greater metabolic activity. This 'dilution' of metabolic activity by the presence of inactive connective tissue does not arise when activity is measured cell by cell as it is by microdensitometry.

The reasons for the increased glycolytic activity of human synovial lining cells in rheumatoid arthritis are unknown. It may simply be a response to the lower oxygen content of rheumatoid synovial fluid (Lund-Olesen, 1970). Conversely, the increased activity may signify a general elevation of metabolic activity, though the activity of mitochondrial oxidation is not similarly enhanced (Henderson et al., 1978). However, it seems certain that the ability of the rheumatoid synoviocytes to produce ATP is not impaired by decreased glycolysis.

We are grateful to $\mathrm{Mr}$ B. Cashman, FRCS, and $\mathrm{Mr} \mathrm{A}$ Catterall, FRCS, for their interest in this work and for supplying the specimens. We are glad to acknowledge a grant towards this work from the Medical Research Council and the support of the Arthritis and Rheumatism Council for Research.

\section{References}

Butcher, R. G., Bitensky, L., Cashman, B., and Chayen, J. (1973). Differences in the redox balance in human rheumatoid and non-rheumatoid synovial lining cells. Beiträge zur Pathologie, 148, 265-274.

Chayen, J., Bitensky, L., and Butcher, R. G. (1973). Practical Histochemistry. Wiley: New York and London.

Dingle, J. T. M., and Page-Thomas, D. P. (1956). In vitro studies on human synovial membrane. A metabolic comparison of normal and rheumatoid tissue. British Journal of Experimental Pathology, 37, 318-323.

Eggleston, L. V., and Krebs, H. A. (1974). Regulation of the pentose phosphate cycle. Biochemical Journal, 138, 425435. 
Henderson, B. (1976). Quantitative cytochemical measurement of glyceraldehyde 3-phosphate dehydrogenase activity. Histochemistry, 48, 191-204.

Henderson, B. (1977). Quantitative cytochemical studies of rheumatoid arthritis. Ph.D. thesis, Brunel University.

Henderson, B., Bitensky, L., and Chayen, J. (1978). Mitochondrial oxidative activity in human rheumatoid synovial lining cells. Annals of the Rheumatic Diseases (in press).

Höhmann, B., and Zwiebel, R. (1971). Selection of enzymes for activity measurements in energy metabolism. A new parameter of reference for activity measurements in tissue structures. Recent Advances in Quantitative Histo- and Cytochemistry, p. 348. Edited by U. C. Dubach and U. Schmidt. Hans Huber: Vienna.

Lund-Olesen, K. (1970). Oxygen tension in synovial fluids. Arthritis and Rheumatism, 13, 769-776.
Newsholme, E. A., and Start, C. (1973). Regulation in Metabolism. Wiley: New York and London.

Page-Thomas, D. P., and Dingle, J. T. M. (1955). In vitro studies of rheumatoid synovium. Preliminary metabolic comparison between synovial membrane and villi. British Journal of Experimental Pathology, 36, 195-198.

Roberts, J. E., McLees, B. D., and Kerby, G. P. (1967). Pathways of glucose metabolism in rheumatoid and nonrheumatoid synovial membrane. Journal of Laboratory and Clinical Medicine, 70, 503-511.

Ropes, M. W., Bennet, G. A., Cobb, S., and Jessar, R. A. (1959). Diagnostic criteria for rheumatoid arthritis. Annals of the Rheumatic Diseases, 18, 49.

Wilkinson, J. H., and Robinson, J. M. (1974). Effect of ATP on release of intracellular enzymes from damaged cells. Nature, 249, 662-663. 